\title{
UNCONSCIOUS MIND AND ANXIETY IN THE MAIN CHARACTER OF FACE IN THE CROWD MOVIE SCRIPT BY JULIAN MAGNAD
}

\author{
Dewi Saktiyah Al Khoiriyah \\ Universitas Diponegoro \\ alkhoiriyahbulan@gmail.com
}

Submit, 27-11-2019 Accepted, 30-12-2019 Publish, 31-12-2019

\begin{abstract}
The objectives of the researcher is to describe Unconscious Mind and Anxiety, this research mainly aimed to answer, 'How is the anxiety reflected in Face in the Crowd movie script?' , 'How do the anxieties lead to fantasy in Face in the Crowd movie script?'. Those two problems are analyzed with Psychological of literature or Psychoanalytical approach. The researcher used a qualitative descriptive method in classifying and analyzing the data, the data was taken from movie script entitled Face In the crowd by Julian Magnat. Then, the result of analysis is the description of unconscious mind and anxiety in the main character. In this analysis the researcher divided it into two main points, such as the anxiety in Face in the Crowd movie script, and the anxieties lead to fantasy. Finally, the conclusion from this analysis there are only a few dialogues that show moral anxieties experienced by Anna. And it can be concluded that is the anxiety felt Anna objectivy reality. Anxiety objectivy reality itself is an anxiety that comes from the fear of the danger in the outside world. Then fantasy does not only occur during sleep but when he appeared conscious but without realizing it. The main character in the film derives satisfaction from fantasies that arise when together with her husband, with the Anna vision abnormalities. And fantasy is a process of daydreaming (dreamy) or imagining action to provide an escafrom reality, with satisfaction the achievements obtained and pleasure that are imaginary or die as a hero who does not sin.
\end{abstract}

Keyword: unconscious mind, anxiety, fantasy, and dream

\section{INTRODUCTION}

The dream is the experience of the unconscious that involves vision, hearing, thought, feeling or other senses in sleep, especially during the sleep that accompanied the rapid eye movement. The occurrence of dreams that usually impossible in the real world, and beyond the power of dreamer. The dream can be said to be the key to human unconsciousness, the dream symbolizes human unconscious desire. 
In this analysis the researcher analyzes movie or film because movie or film is one of literary work that has many problems to be analyzed. people have many different perception to analyze the movie or film script, they will analyze by their imagination. Many people more enjoy watching movie or film than reading book, because they understand more about the contents or the problem. For example in "Face in the Crowd" movie script. Being interested in studying unconscious mind that can be found in the "Face in the Crowd" movie script, the script of this movie has become an important part in movie analysis.

Face in the Crowd movie is one of the films produced in 2011 by Julian Magnad. The main character is Milla Jovovich, Milla Jovovich plays character as a woman named anna. A lady with a normal life and has a job as a teacher in a preschools. Anna has a loving husband named bryec ( michael shanks ), anna have very close freinds who had long existed Francine and nina.

Face in crowd movie script is some movie that tells about unconscious mind in this movie there are many kind of topographical mental (unconscious, pre-conscious, conscious) but the writer will analyze some of it, that is unconscious mind in this movie script.Be specific is fantasy and dream in this movie. In this analyze the researcher uses a theory from Sigmund Freud about the topographical theory.Then from that movie script the researcher finedthe problems which are discussed in this thesis are as a follows: 1.How is the anxiety reflected in Face in the Crowd movie script?2. How do the anxieties lead to fantasy in Face in the Crowd movie script?3.How do the anxieties lead to dream in Face in the Crowd movie script?

Face In The Crowd movie has many similarities movie's name but there different director to produced the movie for example a face in the crowd by Elia Kazan that published on 1957 with different content. and most of journal was published about face in the crowd by elia kazan and most of them talk about fascism in this movie for example "fascism, american style: revisiting kazan and schulberg's a face in the crowd by robert ecksel'. The researcher did not find journal about face in the crowd by Julian Magnat.

The researcher only fined some review about Face InThe Crowd by Julian magnat that published at by the tittle "face in the crowd (2011): ide bagus, eksekusi payah by Firman darmawan". He was critic the genre of face in crowd movie it was not able to be a good quality movies thriller, there are many awkward moment in this movie. Firman's article concern on the genre and the character. Therefore this research was different context discussion between two articles and this research.

In other side even though there is no thesis that analize face in the crowd movie by Julian magnat, but there are similarities concerning in a same theme that analize about uncounsious mind. 
The first is the thesis written by Putra (2018) in this thesis the researcher state that the unconscious mind of Maggie emphasize in three point (id, Ego and Super Ego)and then the researcher find that the unconscious mind is reflected from magie's behavior and her feeling. Sena's research more explain about how the unconscious mind especially id,ego, and super ego make character development. Also,the researcher did not explain about anxiety and fantasy. Second isthe journal written by Rafsanjani, et.al (2015) these journals are explained about the anxiety disorder of Chris as main character. The anxiety in this journal more focused on worry, irritability, bad dream and also restless, but the researcher also analyze from extrinsic elements.

Related the research above, the researcher also analyze about unconscious mind an anxiety of the main character but with different part. Especially, in this analyze the researcher focused on the anxiety of the main character and also the anxiety lead to fantasy.

\section{LITERATURE REVIEW}

In this chapter literary will used to The psychology of literature as a topic includes almost everything about literature. Fundamentally concerned with the articulation of sexuality in language, it has moved through three main emphasis of the literary 'unconscious': on the author, on the reader and on the text.

Psychology in the work of literature, human uses creativity, taste, intention to produce a masterpiece. and psychology literature also recognize literature as a reflection of psychosis. usually the author will use the experience of herself. The researcher using Freud's first model of the mind his topographic model, divided mental possesses what he called unconscious, pre-conscious, and conscious. (Hjelle \& Ziegler, 1992)that make more easier to classified the material of data. Then from topographical model of Freud can be describe three models. The first conscious mind is what you are aware of at any particular moment; this is the aspect of our mental processing that we can think in a rational way. For example, you may be feeling thirsty at this moment and decide to get a drink. Freud said that:

The conscious mind includes such things as the sensations, perceptions, memories, feeling, and fantasies inside of our current awareness. Closely allied with conscious mind is the preconscious, which includes the thing that we are not thinking of at the moment but which we can easily draw into conscious awareness. (Freud, 1920)

The conscious mind includes such things as the perceptions Is identification or interpretation of sensory information in order to fabricate a mental representation through the process of transduction, which sensors in the body transform signal from the environment to encoded neural system.All 
perception involves signals in the nervous system, which result from the sense organs. In other side there are functions that can be showed "The two functions that the capabilities of the conscious mind can address are:Its ability to direct your focus, its ability to imagine that which is not real"

The second one is pre-conscious contains thoughts and feelings that a person is not currently aware of, but which can easily be brought to consciousness. It exists just below the level of consciousness before the unconscious mind.This is what human mean in humaneveryday usage of the word available memory. Human feelings, motives and decisions are actually powerfully influenced by human past experiences, stored in the pre-conscious and instincts from the unconscious. The thirdone is Unconscious MindThe largest part by far is the unconscious. It includes all the things that are not easily available to awareness, including many things that have their origins there, such as our drives or instincts, the memories and emotions associated with trauma. Most of the contents of the unconscious are unacceptable or unpleasant, such as feeling of pain, anxiety, or conflict.

The idea of the psychological unconscious is that at least some of the mental states and processes underlying behavior are either temporarily inaccessible or permanently unavailable to either conscious awareness or conscious control (Kihlstrom, 2007). Since the time of Freud, the psychological unconscious has been one of the most provocative aspects of personality theory and it is also one of the most problematic and controversial.

In the unconscious there is a very prominent part of such dreams and fantasies that occurs in every human being.Fantasy is associated with fantasy or with something that does not really exist and only exist in the mind or the mind alone. Another word for fantasy is imagination. The fantasies of the energy so that there were the realities that lead to conflict and ego fantasies are brought into the subconscious. every human being has a psychological boost, according to the developmental stages of age.

The young lady will dominate erotic fantasy almost exclusively, because ambitious generally incorporated in the erotic longing, the egoistic and ambitious youth will very clearly revealed along with the will of the erotic (Freud, 1962)

Statements above explain that an object in the work of art is a real form of dreams, imagination, and fantasy that have no place in the real world. products such as daydream fantasy is apparent fulfillment of the ambition and erotic desire. in reverie show false happiness and fulfillment of desires on the condition of the reality of life in spite of the sanctions. Unconsciousness is human behavior so that regardless of conscious control. unconscious impulse pure and instinctive. 
Anxiety one of unconscious part According to Freud anxiety as an important part of the personality system, which is a foundation and center of the development of neurosis and psychosis behavior. Freud (Spielberger, 2004) defines anxiety as a certain condition or emotional state that is not pleasant. Usually the person who is experiencing anxiety tends to continuously worried about a bad situation that will befall him. someone who is experienced and anxiety tend not aware, irritability, frequent complaining, difficult concentrate and are easily distracted or have difficulty sleeping sleep.

Beside that Spielberg, et.al, (2004) was given new concept about anxieties that anxieties has two dimension are worry and emotional,which emotional is some reaction because bad thing or good thing then worry or anxiety negative thought about anything. Therefore, the anxiety was some effect from any situation that individuals get, for example the anxieties feeling afraid, panic, lost memory, and confused.

Sometimes, over anxieties makes somebody malfunction in their life it because that person inability to resolved problem but there also minor anxiety that somebody able to make sure they can solve the problem. The individual does not pay attention to real problems that exist, so the individual often does not work or study effectively, and eventually they will become more anxious.

\section{RESEARCH METHOD}

This research applies the liberary research in the form of discriptive qualitative one. qualitative research is used to collect the data in particular topic descriptive (Rahi, 2017) in other word research is interesting in process, meaning, understanding word and picture. The object of study of this research is a script of "Face in the Crowd" movie script. In this study the researcher focused on unconscious mind and the anxiety of the main character.

\section{FINDING}

\section{The Anxiety Reflected through the Main Character of Face in the Crowd Movie Script}

This film tells about a woman named Anna with a normal early life; however an incident changed her. She saw a murder committed by a man to a woman on a pier. At the time the killer saw Anna withnessed him in action so as to make the pursuit of the killer Anna banged up and fell into a deep ocean. After that incident Anna's life changed..

Anxious experience happened when Anna and her husband went to the police station, the following dialogue shows Anna's anxiety. 
Police : This, my friend... is what we have to wade through just to request police protection. Twenty of these get dumped on the Chief's desk e very morning. Cops parked outside your house 24/7 scarfing doughnuts. Strictly 911 territory.]

Anna : He's got my papers. He's got my address.

Police : And he's not stupid enough to go after the one person who can recognize him, right?

(Face in the Crowd, 00:17:52-00:18:16) at police office

Anxiety contained in the above dialogue is when Anna and Bryce are in the police station to ask for protection from the police. The police do not want to give a very strict protection for Anna because of the killer's victims is not only Anna. Anna is still scared because the killer has her address and her phone number, Anna has fear that one day the killer will come to her house when she is alone or call as in the following sentence "He's got my papers. He's got my address "the sentences clarify that Anna still feels the fear of the possibility of her life may still in danger. Since Anna feels that she is the one who sees the killer even though his face is not clear, with such a sense of fear of the killer Anna was without base. Although the police keys: "And he's not stupid enough to go after the one person who can recognize him, right?" Anna still feels that she does not safe from the killer; with the terrified faces facial Anna cannot justify the police is words. What Anna wants almost ignored by the police that become one of the reasons that made Anna suddenly feels frightened at the time.

This dialogue in the climax of Anna's anxieties that showing in the dialogue at subway between Anna and the police in one act but the researcher will analyze to be some part analyzing.

[reading book] : "Be waryof appearances...and an unexpectedinvitation to dinner."

[sirens wailing]

[another place]

Police 1

: Carotid artery andthe larynx are severed, just like the others.Looks like a match.Missed him by minutes.

[cell phone ringing]

Anna : Kerrest.He's here.He's here withme right now.

Police 2(Kerrest) : Whoa, whoa, whoa,whoa, whoa, whoa.What's going on?

Anna : I'm on the subway.And the bag I lost...he put it righton the seat infront of me. 
Police 2(kerrest) : Hold on. You saw him?

Anna : No, but there-there wassomebody watching meoutside the school.Maybe he followed meinto the train.

Furthermore, fears that appear in this dialogue occur when Anna is in a subway while went home after teaching her student. The following sentences according to researchers Anna anxiety began to appear "Kerrest. He's here. He's here with me right now" There, Anna feels that since she is in school there is someone who follows her, especially with the discovery of Anna's bag beside her seat, she is getting anxious and frightened. "I'm on the subway. And the bag I lost, he put it right on the seat in front of me." the second sentence that makes also increasingly becomes frightened. Anna is getting restless to see people who are nearby sees her. She feels safe being on the ground, and then she tries to call the police for protection.

And from the analysis can be described as well as Freud's theory of anxiety, most of the analysis is based on object reality by anxiety . And there are only a few dialogues that show moral anxieties experienced by Anna. And it can be concluded that anxiety is the anxiety felt Anna object reality. Anxiety objects according Freud reality itself is an anxiety that comes from the fear of the danger in the outside world. Whereas according to Freud's own moral anxiety an anxiety about the individual's own conscience. Anna and anxiety felt close relations with each other. Anxiety itself can not be separated from the name of fantasy in this film writers find some anxiety that resulted fantasy starring role in this film.

\section{The Anxieties Lead to Fantasy}

Another analyses that researcher found about anxiety lead to fantasy is in this dialogue The fantasy that researcher found in this dialogue is when Anna continue doing the therapy at doctor.

Doctor : On the countof three...I want youto close your eyes...and travel backin your memories. You can rewind...pause,fast forwardas you wish.I'm countingto three now.Onetwothree.Anna, I want you to go back...to the momentbefore your fall.Is there anybodythere with you?

Anna

: His face is--It's hazy. I can't make outhis features.

Doctor

: Her impairmentis causing a block.

Anna

: I can't getthrough it.

Doctor

: Not evenwith hypnosis.

Kerrest

: She knows. She knowswho she is. 
In this dialogue here fantasy by the researcher formed with hypnosis therapy from doctor to Anna, fantasy is a shadow that appears in the anxieties her experienced during this time. Fantasy is carry out aiming to cure anxiety experienced by Anna, remembering the events of the past murders. As in the following sentence "His face is - It's hazy. I can not make out his features." These sentences illustrate Anna imagine that being the murder incident; imagine the murderer's face but anna feels difficult to imagine the face. that opinion was supported by the following sentence "I can not get through it" that Anna does not able to describe the face of the killer.

\section{DISCUSSION}

In this analysis the researcher described the unconscious mind that concern on the anxiety of the main character Face in the Crowdmovie script by Julian Magnat. This research was identified using Sigmund Freud theory about unconscious mind and the anxiety.

According to Sigmund Freud (Spielberger, 2004) that anxieties is as a certain condition or emotional state that is unpleasant. There are many emotional part in Face In Crowd movie script and also anxieties part that was showed. For examples anxieties part of panic situation " He's got my papers. He's got my address " in this dialogue Anna the main character of this movie was felt scare and also panic because the murder had known her profile.

Anxieties also make somebody confused to distinguish the real life and fantasy its can be occurring because that person felt over worried about anything.Sometimesthey would not get some activity or in other word they was malfunction their life. The researcher also found some anxieties part for example lost memory, it was found in this movie script when the main character forgets his husband face. Lost memory in one of part anxieties because the main character only remembers the murderer faces, so she can distinguish the face.

\section{CONCLUSION}

The conclusion from this analysis there are only a few dialogues that show moral anxieties experienced by Anna. And it can be concluded that is the anxiety felt Anna objectivy reality. Anxiety objectivy reality itself is an anxiety that comes from the fear of the danger in the outside world. Whereas according to Freud's own moral anxiety an anxiety about the individual's own conscience. Anna and anxiety felt close relations with each other. In this analysis the anxiety that Anna felt was many form and Anna always Anxiety itself can not be separated from the name of fantasy in this film writers find some anxiety that resulted fantasy starring role in this film. That fantasy does not only occur during sleep but when he appeared conscious but without realizing it. The main character 
in the film derives satisfaction from fantasies that arise when together with $h$ husband, with the Anna vision abnormalities. And fantasy is a process daydreaming (dreamy) or imagining action to provide an escafrom reality, $w$ satisfaction the achievements obtained and pleasure that are imaginary or die as a hero who does not sin.

\section{REFERENCES}

Freud, S. (1962). Wish fulfillment and Unconscious. In malvin rader, M(ed) (1920). Conscious Mind. England: Times Educational. Ltd.

Hjelle, A \& Daniel, Z. (1992). Personality theories(hardback), US: Mcgraw-hill inc.

Kihlstrom, J., F. (2007). Scientifics Models of Unconscious Mental Activity, University of California: Berkeley.

Spielberger, C.D. (2004). Encyclopedia Od Applied Psychology. Academic press.

Putra, S., P. (2018). Effect Of Maggie's Unconscious Mind To Personality Development In Stephen Crane's Maggie: A Girl Of The Streets.:171.Yogyakarta: Department Of English Letters Faculty Of Letters Sanata DharmaUniversity. http://repository.usd.ac.id/31678/2/144214124_full.pdf

Rafsanjani, H., V., R, \& Muhammad, R. (2015). chris' anxiety symptoms toward her possessed daughter in william peter blatty's the exorcist - gejala kecemasan chris terhadap putrinya yang kerasukan dalam the exorcist oleh william peter blatty. 1-10.Semarang: English Study Program Faculty Of Humanities Dian Nuswantoro University

Rahi, S. (2017). Research Design and Methods: A Systematic Review of Research Paradigms, Sampling Issues and Instruments Development. Malaysia: Int J Econ Manag(:2) Sci 6: 403. doi: 10.4172/2162-6359.1000403 